\title{
TECHNOLOGICAL CHALLENGES IN THE CONTEXT OF TRAINING MODERN LAWYERS
}

\author{
Inna Andreanova \\ Pskov State University, Russian Federation \\ Anna Rozhkova \\ Pskov State University, Russian Federation \\ Ilona Bulgakova \\ Rezekne Academy of Technologies, Latvia
}

\begin{abstract}
The development of modern technologies poses new challenges for training legal professionals. Traditional forms of teaching do not produce the desired secondary effect (for example, the students' interest in acquiring knowledge in a particular course) or the end result (acquiring the competences needed for the modern job market). Consequently, teaching should be more focused on the application of new, non-traditional forms of education while preserving the best traditions of legal training (handwriting rather than e-device, developing communication skills and emotional intelligence). As a result, this article analyses the use of technologies and potential threats they pose to maintaining traditional values specific to the legal profession in the education process. The article, using the method of literature analysis, dialectical research, the deductive and inductive method, analysis and synthesis, and modelling, which ensures the validity of the results obtained, sociological observation method, including as well as the experience of Rezekne Academy of Technologies and of Pskov State University in the training of new lawyers, summarises information and draws conclusions on how to use technology and its development opportunities in the education process.
\end{abstract}

Keywords: education programme, education technologies, information and communication technologies, law, professional competencies.

\section{Introduction}

Currency of the issue of training future lawyers is determined by the review of a complex of educational approaches, technologies, and methods in the modification of students' legal consciousness and legal awareness of the digital transformation of educational and professional space when they perform their legal practice, law enforcement, and expert advisory activity while achieving professional efficacy and a social effect.

Both Russia and Latvia have designed strategies for increasingly greater introduction of technologies in various spheres of life, including the field of Law. 
Development of legal education in Russia as well as Latvia is determined by the legal and regulatory framework, qualification requirements, specific criteria and results for educational institutions in designing education programmes, implementing the academic process for training future specialists, updating educational approaches for launching new professions and work arrangements for a future lawyer.

The leading motive for decreasing inertia in order to improve the training of lawyers, which can certainly promote the effectiveness of policy-making and legal practice, is updating the educational and networking partnership with the professional sector, business community, and governmental institutions of our countries, between both higher education institutions, and other foreign cooperation partners in the creation and launching of digital and professional platforms for the implementation of practice-oriented and interactive education arrangements in various areas of Law.

Thus, in the framework of implementing the Strategy for Development of Information Society in the Russian Federation (hereinafter - Russia) in accordance with the Decree of the President of Russia dated 09.05.2017 No. 203 "On the Strategy for Development of Information Society in Russia for 2017 2030", in the conditions of digital transformation of the legal system, digital competencies of professionals are in demand. Development of new information technologies transforms the institutes of law in the area of public processes: the legal status of a digital profile, the procedure for the identification and authentication of persons in property relations, the legal status of the material situation and smart contracts, the system of government control of cryptocurrency turnover and cryptocurrency transactions, the procedure for online settlement of disputes and legal conflicts, the legal status of cybernetic and information security.

Law specialists are prepared at the Rezekne Academy of Technologies (Latvia), Faculty of Economics and Management, the Legal Science field, and at Pskov State University (Russia), the Faculty of Law. To make sure the training of specialists best corresponds to the modern development trends, both higher education institutions devote special attention to the introduction of new forms of teaching on the basis of the laws and regulations created by the authorities of their respective countries for the development of digital technologies.

The aim of the research is to discover the considerations and prospects of applying educational approaches and methods during the development process for the implementation of education projects using the networking/online and distance solutions as a prospect for restyling current education programmes in different areas of Law.

The following general scientific methods were used in the research process: dialectical research, the deductive and inductive method, analysis and synthesis, 
and modelling, which ensures the validity of the results obtained, sociological observation method.

\section{Discussion and results}

In order to fulfil the provisions of the national projects "Digital Economy in Russia" and "Education" in accordance with the Order of the Government of Russia dated 08.05.2019 No. 570 "On the Implementation of Certain Measures Aimed at the Creation and Development of the Information Resource "Modern Digital Educational Environment in Russia", the proportion of working-age specialists with competitive professional competencies shall amount to $37 \%$ annually in the process of implementing the plan for the achievement of national development objectives until 2024.

When reviewing the issues related to the formation of new competencies of a lawyer on the job market, it would be hard to disagree with the opinion of the authors (Perevalova, Mezenceva, \& Shemshurina, 2019, p. 159) who indicate a number of unsolved problems:

- $\quad$ No linear interdependence of professional and education standards;

- $\quad$ Low diversification of the education track network;

- Insufficient technological supply of digital resources and specialisation platforms; and as a result,

- Low demand for previous professions of a lawyer.

A number of flaws has been found when the authors analysed the Russian national education standards:

- $\quad$ No qualification requirements for lawyers found regarding the use of digital technologies at the level of a basic and professional user where the formation of integrational competencies is possible, determined by the interdisciplinary and networking approach;

- No directions of professional activity and related professional competencies are registered in the field where ICT software is applied;

- During the design of new standards and their synchronisation with professional standards in a short period of time in the form of a project, they become outdated, which calls for a proactive approach to designing education projects.

Currently, in order to form competitive professional competencies, Russian higher education institutions (Serova, 2019, 18) are designing and introducing trending (interdisciplinary) and alternative education programmes. Whereas during the liberalisation of third generation federal education standards while introducing professional standards, it is possible to build individual education tracks, design a competency integration model, which allows personalising the 
education path independently, unlocking the professional potential, with the capacity to eliminate and pre-empt violations of the law and prevent any threats of the digital transformation of the legal system.

For example, in accordance with the requirements of the Federal State Learning Standards for Vocational Higher Education (hereinafter - FGOS VPO) of Russia and the standards for the profession of a competition law specialist and a financial monitoring specialist, the competency integration model of the Master level education project in the field of training 40.04.01 Law, specialty "Legal Regulation of Digital Economy" in Russia contains a set of professional competencies (PC) and specialised professional competencies (SPC).

The competency integration model provides for solving the following problems: - designing a practice-oriented approach to the education process on the basis of digital and professional platforms; - designing learning and teaching support materials in the form of modules in the corresponding academic courses; - interdisciplinary design and modification of existing education programmes in the field of law, economics, information and engineering technologies in the implementation of trending and effective education technologies and methods.

To summarise, updating the qualification features of a modern lawyer, including in accordance with the Order of the Government of Russia dated 18.06.2017 No. 723 "On the Approval of the Provisions for Providing Grants in the Form of Subsidies from the Federal Budget to Federal State Higher Education Institutions", is determined by following an abundance of education criteria, including the integration of technologies in the learning process. For example:- Quality of online courses and skills requirements in the field of online learning; Quality of software, technological infrastructure, government services, integration solutions for the development of single window online learning; Level of diversity and promotion of modern education technologies based on the principles of fundamentalism, science, and technology; Degree of involvement in cooperation with employers in the framework of contractual legal relationships in designing online education products, providing common professional examination platforms and digital platforms for practice-oriented and interactive forms of education.

Based on the experience of leading practitioners and specialists, in Pskov State University, in accordance with the above features, an educational project has been created at the master's level in the field of education 40.04.01 Law, specialty "Legal regulation of the digital economy." In Russia, the program must comply with the requirements of the market and the following regulations: Federal Law “On Education in Russia” dated December 29, 2012 No. 273-Ф3 Based on the experience of leading practitioners and experts, in Pskov State University proposed in accordance with the features above, the Master level 
education project in the field of training 04/40/01 Law, specialty "Legal Regulation of Digital Economy" in Russia needs to correspond to the demands on the market and the following laws and regulations: Federal law "On Education in Russia” dated 12/29/2012 No. 273-FZ; Order of the Ministry of Education and Science of Russia dated 23 August 2017 No. 816 "Procedure for the Use of Electronic Learning, Distance Education Technologies by Educational Organisations during the Implementation of Education Programmes"; Order of the Ministry of Education and Science of Russia dated 14.12.2010 No. 1763 (rev. date 31.05.2011) "On the Approval and Putting into Effect of the Federal State Higher Vocational Education Standard in the field of training 030900 Law (qualification (degree) "Master")”; Order of the Ministry of Labour of Russia dated 09.10.2018 No. 625n "On the Approval of the Professional Standard "Competition Law Specialist"; Order of the Ministry of Labour of Russia dated 24.07.2015 No. 512n "On the Approval of the Professional Standard "Financial Monitoring Specialist (In the Field of Countering the Legalisation (Laundering) of Criminally Obtained Incomes and the Financing of Terrorism)". This register of the fundamental legal principles contains legal regulations for the implementation of project, professional, and granting activity in the field of Law.

Whereas the training of future legal specialists at RTA was started in 1995. In 1995, the Law on Higher Education (Law on Higher Education Institutions, 1995) was adopted and comes into force in Latvia. On 10 June 2010, the Parliament of the Republic of Latvia (hereinafter - Latvia) approved the "Sustainable Development Strategy of Latvia until 2030" (Sustainable Development Strategy of Latvia until 2030, 2010). This strategy stresses the importance of developing the regions of Latvia, the importance of change in the educational paradigm, quality and accessible lifelong education, and quality of education as a development opportunity for Latvia and as a prerequisite for increasing the value of human capital. As for technologies, the strategy stresses that global economy and technologies can significantly change in the next 20 years, and an effective and flexible higher education system is a decisive factor for the competitive capacity of Latvia and the value of human capital. The National Development Plan of Latvia for 2014 also defines the primary areas where the rightfulness and ensuring of effective application of law in any field of activity has an important place.

The programmes implemented at RTA in the "Legal Science" field have been designed on the basis of the Standard for the Profession of a Lawyer (Latv. - Jurista profesijas stadarts) and the Standard for the Profession of an Assistant Lawyer (Latv. - Jurista paliga profesijas standarts), which are mandatory for application in all Law programmes in Latvia. Starting from academic year 2020/2021, Master students in all Law programmes in Latvia will 
be taking a centralised exam in Law in order to certify their qualification of a lawyer. And in the conditions of ensuring a common approach in the "Law Science" field, RTA has also introduced changes in the Master programme to make sure it corresponds to the common requirements provided for by Cabinet Regulation No. 46 dated 14.01.2019 "Procedure for the State Centralised Examination for the Professional Qualification of a Lawyer". The Master education programme in Law (2 years or 4 semesters) and the preceding academic Bachelor programme (3 years) together ensure the fulfilment of the requirements of this common standard. Master students approach the examination test with knowledge in five areas of Law: criminal law/criminal proceedings; civil law/civil proceedings, commercial law; international law and European Union law; constitutional law, administrative law/administrative procedure law; legal theory, legal philosophy, and the history of Latvia. The test consists of two parts: theoretical part and practical part (solving cases in all five areas of Law). It is planned that the qualification exam will be computerized and Master students will be taking the test in the electronic environment using only the legislative database of Latvia on www.likumi.lv for solving cases, and codes will be used.

The RTA e-course (Moodle) system is also actively used in training of young lawyers (www.ekursi.lv).

The education project is unique because a networking approach of RTA and Pskov State University is planned in the implementation of an interdisciplinary, practice-oriented modular and block solution. The prospect of the project is the approbation of the online learning model, trending and effective education methods for forming digital competencies during the implementation of additional education programmes.

The aim of the education project designed by Pskov State University is to prepare professional lawyers who are able to apply digital technologies to the design and application of legal tools when ensuring and protecting the rights of the subjects of legal relationships, court proceedings and enforcement proceedings in the field of digital economy, digital transactions, businessprocess management, databases, electronic signature and personal data, intellectual property and blockchain technologies.

The advantage of the education project is the transfer of professional and IT platforms by education partners and the professional community of employers - programme experts, members of the Academic Council in the organization of practice-oriented activity and the work of project teams in the creation of individual and common projects (orders).

The concept of the Master programme in Law at Pskov State University is filled with trendlines, which form the mission and competitive capacity features of the education project, the segment of the target audience, education paths and 
results, the design of the portrait of a graduate (Figure 1). The concept consists of four modules: the general science and professional module, the module "Practice and Scientific Research: Specialties", and the module "Final State Certification: Research Project", which ends in awarding the qualification "Master".

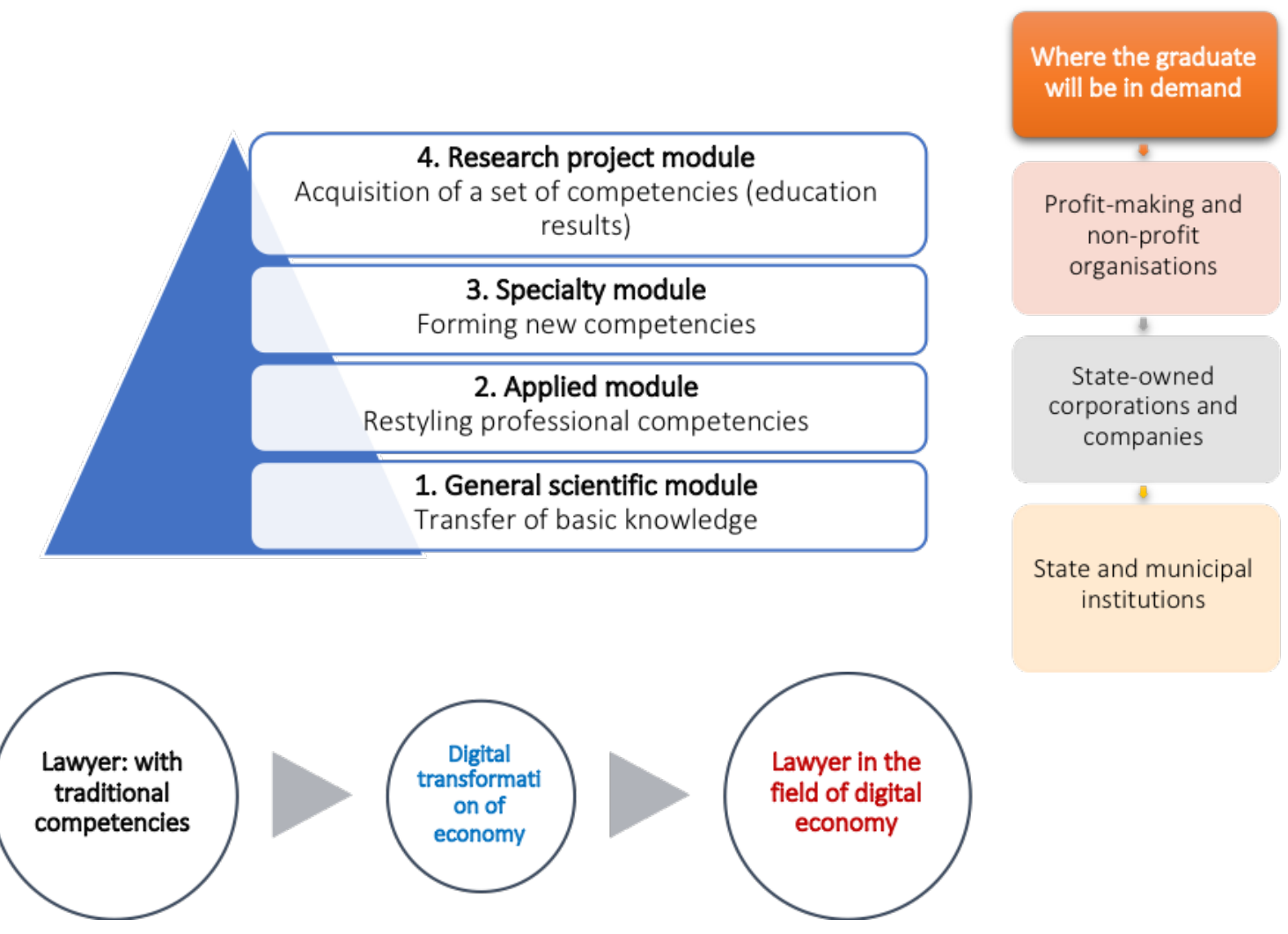

Competency Landscape of a Graduate

Policy-making

Legal practice

Basic and Leadership

Competencies

BC-1, 2, 3, 4

PC-1, 2 + SPC:

Ability to create a strategic vision

Ability to be a leader and a team player

- Striving for professional cooperation and independence
Policy-making

Legal practice

Basic and Leadership

Competencies

BC-1, 2, 3, 4

PC-1, 2 + SPC:

Ability to create a strategic vision

Ability to be a leader and a team player

- Striving for professional

cooperation and independence
Policy-making

Legal practice

Basic and Leadership

Competencies

BC-1, 2, 3, 4

PC-1, 2 + SPC:

Ability to create a strategic vision

Ability to be a leader and a team player

- Striving for professional cooperation and independence

Figure 1 Predicted Portrait of a Graduate (developed by the authors) 
The target audience includes human resources for companies, organisations, and institutions implementing professional activity in the field of digital economy and those in need of digital updating of their knowledge and competencies in these fields.

Flexible and alternative education approaches and methods are planned for personalising education tracks. In this cycle, the first year of education, the socalled exploration year, is related to formulating problems and the motive by the Master students during the acquisition of knowledge. The forms of the learning process are the following: intensive lectures, distance reference form, consultations, intensive meetings with personal approach, work in project teams, independent distance learning, case-studies. Forms of on-going control: exploration essay presentation, monitoring list; digest of legal norms; roadmaps, conclusion and expert evaluation projects. Form of intermediate control: test/ differentiated test/ exam with public approbation of scientific and legal results.

Whereas the second year of education - actualisation of problems in practice - contains such forms of the learning process as online sessions, discourse analysis, work in project teams, synchronous seminars, master classes, action research. Forms of on-going control: discussing prospectuses, roadmaps, models. Form of intermediate control: test/ differentiated test/ exam with public approbation, presenting scientific reviews, scientific articles, theses and portfolio.

The structure of the Master programme forms a complete education cycle (Figure 2) of project logic where education results are prioritised at the level of the programme, module, academic subject, and class, including the (conventionally labelled) integration component 3F: the form of conducting classes, the form of on-going and intermediate control in the acquisition of competencies.

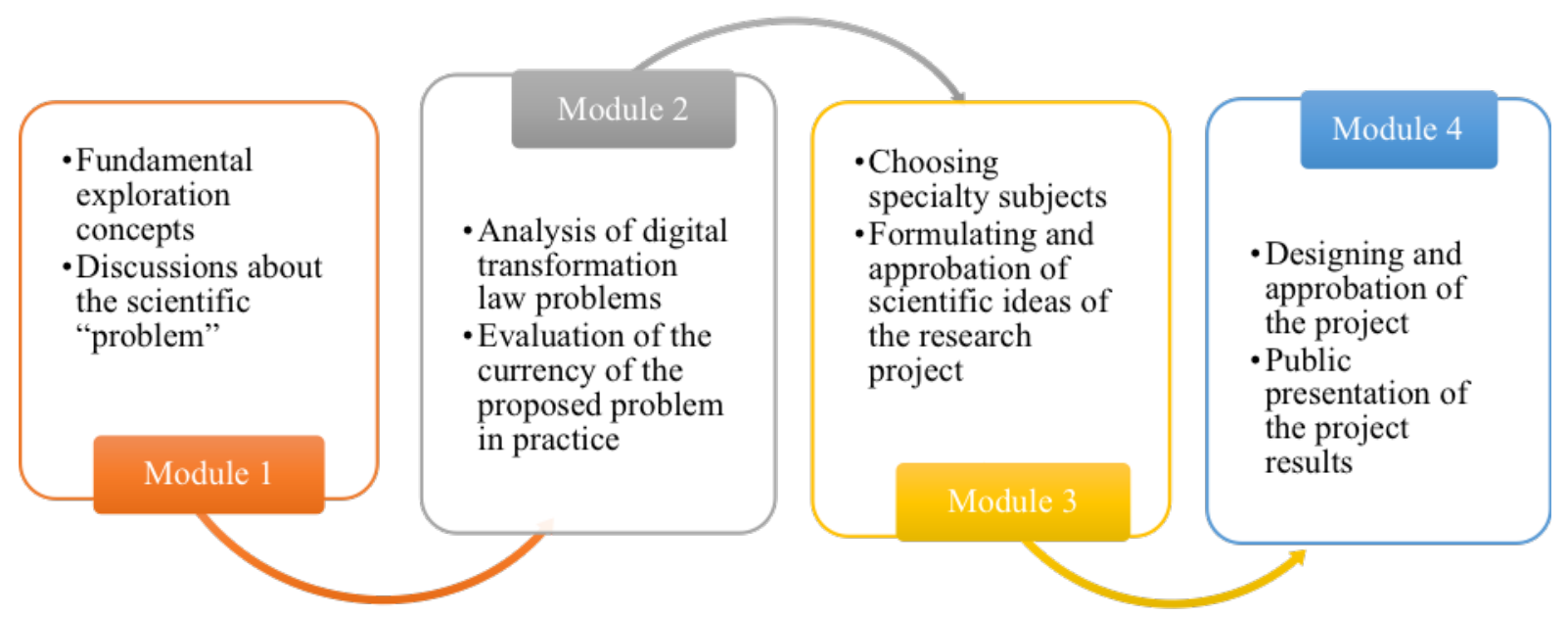

Figure 2 Complete Education Cycle of the Programme (developed by the authors) 


\section{Summary}

Overall, reviewing and launching modern education approaches and methods at Pskov State University can be a factor in applying technological solutions while preserving the principles of fundamentalism, science, and professionalism in the training of lawyers. At the same time, on the basis of the implementation of the common approach, including to the centralized qualification exam in Latvia, the experience of RTA in using technologies, while preserving classic traditions of legal education is imperative, can promote the growth of competitive capacity of RTA graduates on the job market of Latvia and the European Union.

Whereas the implementation of the education project of Pskov State University with the participation of RTA described in this article will promote the development of not only education programmes in Law at Pskov State University and RTA, but also the development of both higher education institutions and the regions in general.

\section{References}

Cabinet Regulation No. 46 dated 14.01.2019 "Procedure for the State Centralised Examination for the Professional Qualification of a Lawyer". Retrieved from https://likumi.lv/ta/id/304369-valsts-vienota-jurista-profesionalas-kvalifikacijaseksamena-kartiba (In the Latvian language).

Decree of the President of Russia dated 09.05.2017 No. 203 “On the Strategy for Development of Information Society in Russia for 2017-2030”. Retrieved from http://www.consultant.ru (In the Russian language).

Federal law "On Education in Russia” dated 29.12.2012 No. 273-FZ. Retrieved from http://www.consultant.ru (In the Russian Language).

Law on Higher Education Institucions. (1995). Retrieved from https:/likumi.lv/ ta/en/en/id/37967-law-on-higher-education-institutions (In the Latvian language).

National Development Plan of Latvia for 2014-2020. (2012). Retrieved from https:/likumi.lv/ta/id/253919-par-latvijas-nacionalo-attistibas-planu-2014-2020-gadam (In the Latvian language).

Order of the Government of Russia dated 18.06.2017 No. 723 "On the Approval of the Provisions for Providing Grants in the Form of Subsidies from the Federal Budget to Federal State Higher Education Institutions”. Retrieved from http://www.consultant.ru/ document/cons_doc_LAW_218252/92d969e26a4326c5d02fa79b8f9cf4994ee5633b/ (In the Russian language).

Order of the Ministry of Education and Science of Russia dated 23 August 2017 No. 816. "Procedure for the Use of Electronic Learning, Distance Education Technologies by Educational Organisations during the Implementation of Education Programmes" Retrieved from http://www.consultant.ru/document/cons_doc_LAW_324367 (In the Russian language).

Order of the Ministry of Education and Science of Russia dated 14.12.2010 No. 1763 "On the Approval and Putting into Effect of the Federal State Higher Vocational Education Standard in the field of training 030900 Law (qualification (degree) "Master")". Retrieved from http://www.consultant.ru/document/cons_doc_LAW_110623 (In the Russian language).

Order of the Ministry of Labour of Russia dated 09.10.2018 No. 625n "On the Approval of the Professional Standard "Competition Law Specialist" Retrieved from http://www.consultant.ru/document/cons_doc_LAW_310306 (In the Russian language). 
Order of the Ministry of Labour of Russia dated 24.07.2015 No. 512n "On the Approval of the Professional Standard "Financial Monitoring Specialist (In the Field of Countering the Legalisation (Laundering) of Criminally Obtained Incomes and the Financing of Terrorism)” Retrieved from http://www.consultant.ru/document/cons_doc_LAW_ 185097 (In the Russian language).

Order of the Government of Russia dated 08.05.2019 No. 570 "On the Implementation of Certain Measures Aimed at the Creation and Development of the Information Resource "Modern Digital Educational Environment in Russia". Retrieved from http://www.consultant.ru/document/cons_doc_LAW_324367/ (In the Russian lauguage).

Perevalova, M.N., Mezenceva, L.V., \& Shemshurina, S.A. (2019). Rynok truda: problema podgotovki specialista $\mathrm{V}$ sfere jurisprudencii cherez formirovanie neobhodimyh kompetencij. Vestnik VUiT, 1, 158-162. (In the Russian language).

Serova, O.A., \& Zajcev, V.V. (2019). Cifrovaja jekonomika: problemy pravovogo regulirovanija. Moskva: KNORUS, 200. (In the Russian language).

Sustainable Development Strategy of Latvia until 2030. (2010). Retrieved from https://www.pkc.gov.lv/sites/default/files/inline-files/LIAS_2030_en_1.pdf (In the Latvian language). 